Kajian Jurnalisme

ISSN 2549-0559 (cetak) ISSN 2549-1946 (online)

Volume 02 Nomor 01 Tahun 2018

\title{
Strategi Manajemen Redaksi Majalah Mingguan Mangle Di Era Digital
}

\author{
Noviany Suryani dan Henny Srimulyani \\ Program Studi Jurnalistik, Fakultas Ilmu Komunikasi, Universitas Padjadjaran \\ E-mail: suryaninoviany@gmail.com
}

\begin{abstract}
The thesis aims to find out how Mangle editorial management before and after their releasing online portal. Then to find out what is the main purpose and expectation from their online portal, and to find out the strategy that Mangle use to adapt in digital era. This thesis using qualitative method with case study approach. The result show Mangle editorial management before releasing online portal was run effectively. After it release, editorial workflow changing caused by immature organizing at the beginning of its implemetation. The second result is main purpose and expectation from their online portal initially was just to reach the readers outside Indonesia so they can enjoy Mangle eventhough they are not in the distribution area. As time goes by, there is more purpose that Mangle want to pursue because they realize online media can be used more than just as promotion platform. The third result is the strategy that Mangle used can be said not yet meet the standard. It is visible from the content which not updated periodically, caused by strategy media management activity that not be done.
\end{abstract}

Keywords: media management, media management strategy, newmedia

\begin{abstract}
Abstrak
Penelitian ini bertujuan untuk mengetahui bagaimana manajemen redaksi Mangle sebelum dan sesudah mengeluarkan portal online. Kemudian untuk mencari tahu apa tujuan dan ekspektasi dari pembuatan portal online, serta mengetahui strategi yang dilakukan Mangle dalam beradaptasi di era digital lewat media onlinenya tersebut. Penelititan menggunakan metode penelitian kualitatif dengan pendekatan studi kasus. Hasil penelitian menunjukan bahwa manajemen redaksi Mangle sebelum portal online berjalan cukup efektif. Setelah kemunculannya, alur kerja redaksi mengalami perubahan yang disebabkan pengorganisasian yang kurang matang di awal pelaksanaanya. Temuan kedua tujuan dan ekspektasi Mangle terhadap portal online awalnya hanya menjangkau pembaca di luar Indonesia agar pembaca bisa menikmati Mangle meski tidak berada di area distribusinya. Namun seiring berjalannya waktu, banyak keinginan lain yang ingin dicapai melalui portal onlinenya karena mereka menyadari fungsi media online yang lebih dari media promosi. Temuan ketiga strategi yang dilakukan Mangle dapat dikatakan belum memenuhi standar. Hal ini terlihat dari kontennya yang tidak diperbarui secara berkala, akibat banyak aktivitas strategi manajemen media yang tidak dilaksanakan.
\end{abstract}

Kata kunci: manajemen media, strategi manajemen media, media baru 
2 | Kajian Jurnalisme

ISSN 2549-0559 (cetak) ISSN 2549-1946 (online)

Volume 02 Nomor 01 Tahun 2018

\section{Pendahuluan}

Perkembangan teknologi saat ini membuat masyarakat kita bergeser ke arah era multimedia. Berkat teknologi, informasi dapat diakses dengan mudah kapan pun dan di mana pun. Menurut Castells, dalam Ibrahim (2014: 104), teknologi media baru mungkin "membentuk ulang basis material bagi masyarakat" (Castells 1966:1), yang memungkinkan terjadinya proses globalisasi melalui kapasitasnya untuk mendistribusikan informasi dengan tahap yang cepat dan volume yang tinggi. Untuk mengimbangi kecepatan arus informasi, tentunya industri pers perlu ikut menyesuaikan diri demi mempertahankan eksistensinya.

Banyak media telah menerapkan sistem konvergensi ini demi memenuhi tantangan zaman. Media-media tradisional kini mulai memunculkan berbagai platform yang memudahkan khalayak untuk mengakses informasi. Tidak terkecuali majalah berbahasa Sunda, Manglé. Sebagai satu-satunya majalah mingguan berbahasa Sunda yang ada di dunia, Manglé ikut serta menerapkan konsep konvergensi dengan meluncurkan situs www.mangleonline.com pada tahun 2012. Versi cetak dari majalah Manglé masih konsisten terbit sejak tahun 1957 hingga saat ini.

Berdasarkan pengakuan Redaktur Pelaksana Manglé Ensa Wiarna, kemunculan mangle-online.com dilatarbelakangi oleh semangat awak redaksi dalam menjawab tantangan zaman. Dalam keterangan profil media pada situs Manglé online disebutkan bahwa kemunculannya dilatar belakangi oleh respon baik pembaca setia Manglé dan sebagai salah satu upaya menghadapi era globalisasi. Manglé juga menyebutkan bahwa visinya adalah ingin menjaga, memelihara bahasa, sastra dan filosofi Ki Sunda; menjadi media online untuk menyampaikan informasi tentang budaya Sunda ke penjuru dunia; media alat tukar pikiran orang-orang Sunda atau orang yang peduli terhadap perkembangan budaya daerah dalam peran pembangunan; menjaga dan melestarikan budaya Sunda dengan berbagai kalangan etnis lainnya; serta profit oriented yang seimbang, antara rasa memiliki terhadap budaya Sunda dengan taraf hidup pada masanya.

Konsep awal platform online Manglé cukup sederhana. Tetap konsisten dengan menggunakan bahasa Sunda sebagai bahasa redaksional, berita-berita yang ada pada Manglé versi cetak kemudian diterbitkan pada portal onlinenya. Ensa mengatakan, tentunya hanya berita-berita pilihan yang bisa diterbitkan di mangleonline.com. Biasanya, mereka memasukan berita-berita yang tak lekang oleh waktu. Dari 26 rubrik yang ada pada majalah Manglé, 13 rubrik favorit pembaca dihadirkan kembali pada platform onlinenya. Perbedaannya, dalam platform online ditambahkan 7 rubrik khusus yang berbeda dengan yang ada di cetak. Sejak awal kemunculannya, berita serta konten hiburan dalam situs online Manglé aktif diperbarui setiap harinya. Sayangnya, kini pengelolaannya terkesan mengalami hambatan hingga terakhir kali kontennya diperbarui pada tahun 2015.

Berdasarkan situs penyedia informasi data komersial traffic web, Alexa.com per September 2017, mangle-online.com menempati peringkat 170.886 di Indonesia. Peringkatnya tertinggal jauh dari panjebarsemangat.co.id, salah satu majalah mingguan berbahasa Jawa, yang menempat posisi ke 62.821. Begitu juga dengan total jumlah 
pengunjung websitenya yang hanya mencapai 50\% meski naik sebesar $17 \%$ dari 3 bulan sebelumnya. Grafik lalu lintas website mangle-online.com tidak dapat diperlihatkan Alexa.com karena website Mangle yang baru saja kembali beroperasi setelah 2 bulan lalu sempat mengalami perbaikan.

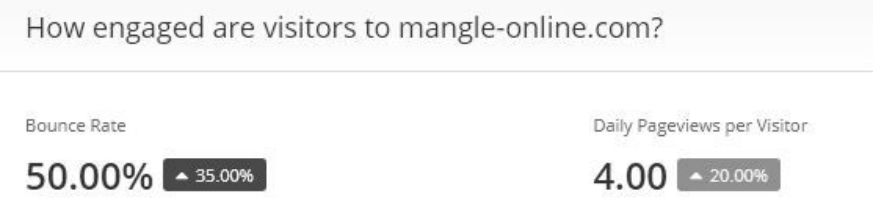

Where do mangle-online.com's visitors come from?

Search Traffic

What percentage of visits to this site come from a search engine?

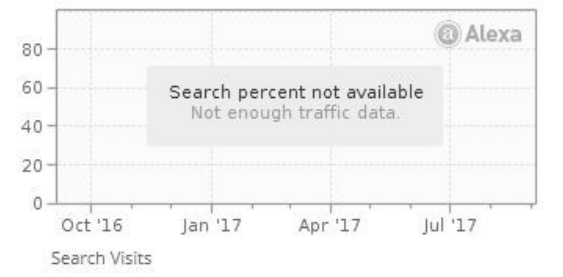

$50.00 \%$

Gambar 1 Lalu Lintas mangle-online.com berdasarkan Alexa.com

Dalam sejarah media berbahasa Sunda, Manglé termasuk majalah yang bertahan cukup lama. Sejak awal berdiri pada tahun 1957 sampai sekarang, Manglé sudah memasuki tiga fase, yaitu masa Orde Lama, Orde Baru, dan Reformasi. Pada dekade tahun 1960-an, oplah majalah Mangle sempat mencapai 90.000 eksemplar. Kini, oplah majalah Manglé hanya 7500 saja. Meski mengalami jatuh bangun dalam pengelolaan medianya, Manglé tetap konsisten mengemban misi menjadi media yang bertujuan untuk melestarikan sastra dan budaya Sunda sebagai media komunikasi orang-orang Sunda sampai akhir zaman. Perjuangan yang dilakukan Manglé untuk mempertahankan eksistensinya selama 60 tahun tentunya tidak selalu mulus. Mulai dari kantor redaksinya yang sampai tiga kali berganti lokasi hingga teknik percetakannya yang berawal dari sistem lettering press sampai sekarang memiliki mesin cetaknya sendiri. Bukan hanya itu, pemilihan konten dan strategi pemasarannya pun telah mengalami berbagai evolusi.

Berdasarkan hasil penelitian yang bertajuk Perkembangan Majalah Manglé di Bandung (1998-2012) yang ditulis Wineu Wahyuni, disebutkan bahwa keberhasilan majalah Manglé dalam mempertahankan eksistensinya adalah berkat adanya pembaca setia yang masih berlangganan majalah Manglé hingga hari ini. Karena itulah Manglé agak sulit untuk didapat secara eceran. Keberhasilannya ini membuat Manglé terkesan merasa cukup dengan titel yang penting masih hidup dan menerbitkan majalah. Sehingga pengelolaan situs www.mangleonline.com yang pernah diluncurkan menjadi terabaikan begitu saja. 
4 | Kajian Jurnalisme

ISSN 2549-0559 (cetak) ISSN 2549-1946 (online)

Volume 02 Nomor 01 Tahun 2018

Padahal, hasil survei UC Browser tahun 2016 menunjukkan bahwa $95.4 \%$ pengguna Internet di Indonesia mengakses berita dari telepon seluler. Disusul televisi sebanyak $45.9 \%$, koran/majalah sebanyak $20.9 \%$, komputer personal $15.3 \%$ dan radio sebanyak $6.7 \%$. Indonesia juga tercatat memiliki angka tinggi dalam konsumsi media senilai 540 menit per hari. Konsumsi media di perangkat mobile mencapai 291 menit per hari, lebih tinggi dari konsumsi media di TV dan PC. Hal ini menunjukkan bahwa tingkat konsumsi jenis media di Indonesia mulai bergeser secara signifikan menyesuaikan dengan era konvergensi. Masyarakat kini mulai meninggalkan mediamedia konvensional dan beralih ke online. Bila dimanfaatkan, tentunya Manglé dapat mengembangkan eksistensinya dan tidak hanya terpaku pada versi cetak dan pelanggan setia. Sebab, bila Manglé masih ingin mempertahankan sastra dan budaya Sunda hingga akhir zaman, ia perlu menyesuaikan diri dengan era globalisasi saat ini. Menurut Green (dalam Ibrahim, 2014: 103) teknologi dipahami sebagai sistem dan mesin yang kita gunakan untuk membereskan sesuatu. Karena itulah, kemajuan dalam bidang teknologi komunikasi memiliki konsekuensi luar biasa bagi kehidupan kebudayaan, ekonomi, dan politik. Teknologi, misalnya menentukan dengan cara apa informasi diproses, ditransfer dan diekspresikan secara kreatif.

Peneliti ingin meneliti tentang strategi dan evaluasi yang dilakukan redaksi Mangle dalam beradaptasi dengan media baru di era digital yang bisa dibilang belum cukup baik. Peneliti ingin mengetahui apa strategi yang dilakukan oleh Mangle dalam mengelola dan mempertahankan platform online mereka di era serba digital seperti sekarang ini. Masalah yang diteliti dalam penelitian ini adalah bagaimana strategi manajemen redaksi Mangle dalam beradaptasi di era digital. Penelitian ini bertujuan untuk mengetahui sistem dan pola kerja redaksi Mangle pada saat sebelum dan sesudah munculnya portal online. Selain itu, penelitian ini juga bertujuan untuk mengetahui tujuan Mangle mengeluarkan portal online dan bagaimana strategi yang mereka gunakan dalam beradaptasi di era digital.

\section{Metode}

Penelitian ini menggunakan metode penelitian kualitatif yang merupakan suatu pendekatan atau penelusuran untuk mengeksplorasi dan memahami suatu gejala sentral. Untuk mengerti gejala sentral tersebut, peneliti mewawancarai peserta penelitian atau partisipan dengan mengajukan pertanyaan yang umum dan agak luas. Hasil penelitian kualitatif sangat dipengaruhi oleh pandangan, pemikiran, dan pengetahuan peneliti karena data tersebut diinterpretasikan oleh peneliti.

Metode penelitian studi kasus, peneliti anggap cocok untuk penelitian ini. Sebab, studi kasus merupakan bagian dari metode kualitatif yang hendak mendalami suatu kasus tertentu secara lebih mendalam dengan melibatkan pengumpulan beraneka sumber informasi. Creswell, dalam Raco (2010: 49) mendefinisikan studi kasus sebagai suatu eksplorasi dari sistem-sistem terkait (bounded system) atau kasus. Suatu kasus menarik untuk diteliti karena corak kaus tersebut yang memiliki arti pada orang lain, minimal bagi peneliti.

Dalam penelitian ini, peneliti menggunakan metode studi kasus kajian Robert E. Stake dalam Denzin \& Lincoln (1994). Berdasarkan minat dan jenisnya, Stake mengidentifikasi tiga jenis kajian studi kasus, yaitu: 1) Studi kasus intrinsik, tujuan peneliti yang ingin lebih 
memahami sebuah kasus tertentu; 2) Studi kasus instrumental, bertujuan untuk meneliti suatu kasus tertentu agar tersaji sebuah perspektif tentang isu atau perbaikan suatu teori; 3) Studi kasus kolektif, bertujuan untuk meneliti sejumlah kasus secara bersamaan agar dia bisa meneliti fenomena, populasi, atau kondisi umum.

Mengingat tujuan peneliti yang hendak memahami lebih jauh mengenai sebuah kasus, maka peneliti memutuskan untuk menggunakan studi kasus intrinsik. Dalam meneliti menggunakan studi kasus intrinsik, seorang peneliti perlu mengabaikan rasa keingintahuannya yang lain agar kasusnya dapat memunculkan kisah uniknya sendiri. Dalam penelitian ini, masalah atau kasus yang diteliti adalah kemunculan mangle online sebagai proses adaptasi Mangle di era digital. Peneliti berusaha memahami lebih jauh mengenai apa yang terjadi pada redaksi Mangle hingga pengelolaan portal onlinenya tidak berjalan dengan baik.

Teknik pengumpulan data dilakukan dengan cara wawancara, observasi dan studi literasi. Penelitian ini didukung oleh tinjauan beberapa penelitian sebelumnya yang berkaitan dengan strategi manajemen media massa dalam melakukan konvergensi atau beradaptasi di era media baru. Penelitian yang dimaksud adalah: penelitian yang dilakukan oleh Jessica Patricia Tanjung dengan judul Konvergensi Media di Tengah Persaingan Bisnis Radio di Surabaya; Penelitian yang dilakukan oleh Artista Lushar Nova dengan judul Model Pengelolaan Juara.Net Sebagai Sinergi Unit Dalam Menghadapi Persaingan Bisnis Media; Penelitian yang dilakukan oleh Gema Arinda Tanjung yang berjudul Budaya Kerja Redaksi Media Tabloid Nova Pada Era Konvergensi; dan Penelitian yang dilakukan Wineu Wahyuni dari Fakultas Dakwah dan Ilmu Komunikasi Universitas Islam Negeri Sunan Gunung Djati Bandung yang berjudul Perkembangan Majalah Mangle di Bandung (1957-2012).

Selain itu, penelitian ini juga menggunakan beberapa kajian pustaka mengenai beberapa topik yang berkaitan dengan manajemen media di era digital. Pertama adalah kajian mengenai komunikasi massa. Komunikasi massa adalah sebuah proses penyampaian pesan lewat media yang ditujukan pada khalayak luas yang tersebar dan heterogen. Arthur Asa Berger menegaskan bahwa:

"Mass communication involves the use of print or electronic media, such as newspapers, magazines, film, radio, or television, to communicate to large numbers of people who are located in various places - often scattered all over the country or world. The people reached may be in groups of varying sizes or may be lone individuals. A number of different elements make up mass communication media; images, spoken language, printed language, sound effect, music, color, lighting and a variety of other techniques are used to communicate messages and obtain particular effects." (1995:12)

Deddy Mulyana (2007: 78-80) menambahkan, yang membedakan komunikasi massa dengan konteks komunikasi lainnya adalah adanya media (channel) dengan jarak fisik yang rendah (komunikan-komunikator jauh). Tidak seperti dalam komunikasi tatap muka yang memungkinkan semua indera, potensi masukan yang diindera komunikan dalam komunikasi massa lebih terbatas. 
6 | Kajian Jurnalisme

ISSN 2549-0559 (cetak) ISSN 2549-1946 (online)

Volume 02 Nomor 01 Tahun 2018

Selanjutnya adalah kajian mengenai media baru. Istilah media baru sesungguhnya telah dikenal sejak tahun 1960-an yang merujuk pada penggunaan perangkat teknologi komunikasi. Istilah ini kemudian menjadi populer digunakan untuk menjelaskan fenomena perubahan yang terjadi di dunia media dan komunikasi. Pengguna media telah berubah dan sekarang harus berkompetisi dengan media yang bermacam-macam. Shanahan dan Morgan (dalam Turner, 2008: 11) mengemukakan bahwa terdapat konsistensi lingkungan dari isi pesan yang kita konsumsi dan pada sifat dasar dari lingkungan simbolik di mana kita hidup meski jika terjadi perubahan distribusi teknologi. Mereka menambahkan bahwa teknologi baru selalu dikembangkan dengan mengadopsi isi pesan dari teknologi dominan sebelumnya. Marshall McLuhan (dalam Turner, 2008: 12) melihat bahwa media baru hanya sekadar menyediakan botol baru untuk anggur yang lama.

Selanjutnya adalah kajian mengenai konvergensi media massa. Banyak orang menggunakan istilah konvergensi dalam dunia profesional merujuk pada proses di mana terjadi penggabungan dalam tim editorial. Hal ini dianggap sebagai salah satu solusi logis terhadap fenomena yang saat ini sedang populer di kalangan perusahaan media, sebagai cara beradaptasi menghadapi tantangan lingkungan digital dan peningkatan produktivitas dari sumber daya manusia dan material. Eugene Siapera dan Andreas Veglis (2012) membagi pengertian konvergensi berdasarkan beberapa tipe, yaitu konvergensi sebagai produk; konvergensi sebagai sistem, serta konvergensi sebagai proses

Kemudian ada kajian mengenai manajemen media massa. Manajemen menurut John D. Millet (dalam Sukarna, 2011: 2) adalah proses pembimbingan dan pemberian fasilitas terhadap pekerjaan orang-orang yang terorganisir dalam kelompok formil untuk mencapai suatu tujuan yang dikehendaki. Menurut Torang, (2013: 165) manajemen berorientasi pada proses (process oriented) yang berarti bahwa manajemen membutuhkan sumber daya manusia, pengetahuan, dan keterampilan agar aktivitas menjadi lebih efektif atau dapat menghasilkan tindakan dalam mencapai kesuksesan. Oleh sebab itu, tidak akan ada organisasi yang akan sukses apabila tidak menggunakan manajemen yang baik. Begitu pula dengan organisasi di industri media.

George R. Terry, salah tokoh dalam dunia manajemen mengemukakan bahwa ada empat fungsi dalam manajemen yaitu planning, organizing, actuating dan controlling yang lebih dikenal dengan sebutan POAC. Ia juga menyebutkan adanya 6 unsur yang membentuk manajemen yang dikenal dengan istilah 6M yaitu, man (manusia), materials (bahan-bahan), machine (mesin atau alat), methods (metode), money (uang) dan market (pasar).

Selanjutnya adalah kajian mengenai teori strategi manajemen media massa. Stephanie K. Marrus (dikutip Sukristono, 1995) mendefinisikan strategi sebagai suatu proses penentuan rencana para pemimpin puncak yang berfokus pada tujuan jangka panjang organisasi, disertai penyusunan suatu cara atau upaya bagaimana agar tujuan tersebut dapat dicapai.

Albaran menyebutkan (2008:41) isu mengenai strategi manajemen media menjadi teori atau kerangka konseptual dalam studi mengenai manajemen media yang paling banyak digunakan. Beberapa studi kasus dan studi analisis digunakan dalam upaya memahami mengapa beberapa industri media lebih baik dari yang lain, yang mana menjadi fokus utama penelitian strategi manajemen di industri media. Namun, Hamlin (2001: 16) menemukan 
berbagai literatur yang menyebutkan banyak contoh kegagalan manajerial baik dalam hal formulasi maupun implementasi strategi, terutama strategi yang melibatkan perkembangan dan perubahan organisasi yang signifikan. Area konsep teori strategi manajemen biasanya berfokus pada isuisu seperti memberikan penjelasan strategi dari konsentrasi pasar media, adaptasi terhadap perubahan kondisi pasar, atau menjelajahi strategi opsi untuk perusahaan yang beroperasi dalam berbagai pasar dan setting regulasi.

Selanjunya adalah kajian mengenai pendekatan value chain yang dicetuskan Michael E. Porter. Pendekatan ini memandang perusahaan sebagai suatu rangkaian atau jaringan aktivitas dasar yang menambah niliai bagi produk atau jasanya. Dalam konteks industri media, maka produk atau jasa yang dimaksud adalah proses produksi berita dari pencarian informasi awal hingga mencapai khalayaknya.

Analisis Value Chain menggambarkan aktivitas di dalam dan disekitar organisasi dan menghubungkannya pada kekuatan persaingan perusahaan. Menurut Porter (1985: 33), " $A$ value chain disaggregates a firm into its strategically relevant activities in order to understand the behavior of costs and the existing and potential sources of differentiation". Intinya, Value Chain membicarakan soal proses pembuatan produk (dalam penelitian ini produk media yaitu berita) sejak nilai asli sampai hasil jadi, dengan aktivitas-aktivitas yang dapat dibagi-bagi dan lebih efisien. Analisis Value Chain dapat membantu peneliti untuk melihat seperti apa proses yang dilakukan bagian redaksi Mangle terhadap pembentukan produk portal online mereka, serta menemukan peluang agar prosesnya menjadi lebih efektif dan efisien.

\section{Hasil dan Pembahasan Hasil Penelitian Manajemen Mangle Saat Ini}

Mangle adalah majalah berbahasa daerah, lebih spesifik yaitu majalah berbahasa Sunda yang telah terbit sejak tahun 1957. Saat ini, ia menjadi satu-satunya majalah berbahasa yang masih aktif dan terus terbit di Jawa Barat dan di dunia. Majalah Mangle pertama kali terbit di Bogor, kemudian memindahkan pusat redaksinya ke Bandung. Alasannya sederhana, sebab segala kegiatan pemerintahan dan budaya Sunda berpusat di Bandung sebagai Ibu Kota Jawa Barat.

Awalnya konten Mangle 95\% berisi dongeng, cerita pendek, anekdot dan kontenkonten budaya lainnya. Sehingga wartawan Mangle kebanyakan tidak perlu pergi ke lapangan untuk membuat materi konten majalah dan tidak memerlukan kemampuan jurnalistik untuk mencari, mengolah dan menyajikan berita. Sampai saat ini pun, tidak ada karyawan lulusan jurnalistik yang bekerja di Mangle. Hal ini disebabkan karena konten Mangle disesuaikan dengan kebutuhan masyarakat Sunda yang memang lebih membutuhkan konten hiburan serta human interest dibanding konten news.

Penentuan isu setiap minggunya dilakukan setiap Kamis, karena setiap Kamis pula majalahnya terbit. Biasanya setelah makan siang, rapat redaksi akan diselenggarakan untuk brain storming, isu-isu apa saja yang akan dinaikan di edisi selanjutnya. Isu yang diangkat tidak harus selalu mengandung unsur kebaruan. Yang penting, isunya tidak mudah basi. Selain itu, cara penulisannya harus diangkat dari sudut pandang kesundaan. Meskipun setiap rubrik ada redaktur yang memegang, namun untuk isu semua orang bisa mengajukan untuk rubrik mana pun. 
8 | Kajian Jurnalisme

ISSN 2549-0559 (cetak) ISSN 2549-1946 (online)

Volume 02 Nomor 01 Tahun 2018

Alur pengerjaan dan pembagian tugas dilakukan saat itu juga, di rapat redaksi setelah semua isu ditetapkan. Karena untuk wartawan, tidak dibagi per desk. Setiap wartawan bisa menulis untuk rubrik mana saja. Ketika ke lapangan, wartawan dibekali bukan hanya arahan, tapi juga pertanyaan dan narasumber yang menjadi sumber informan. Setelah itu, wartawan akan mengolah hasil liputannya dan dikirim ke redaktur desk masing-masing. Setelah melewati proses editing oleh redaktur masing-masing, hasil tulisannya diberikan ke Pemimpin Redaksi untuk dicek sekali lagi, diedit bila masih ada kesalahan, baru diberikan kepada layouter untuk dilayout hingga siap cetak.

Bila dibuat bagan, seperti inilah alur dan sistem pembagian kerja Mangle cetak:

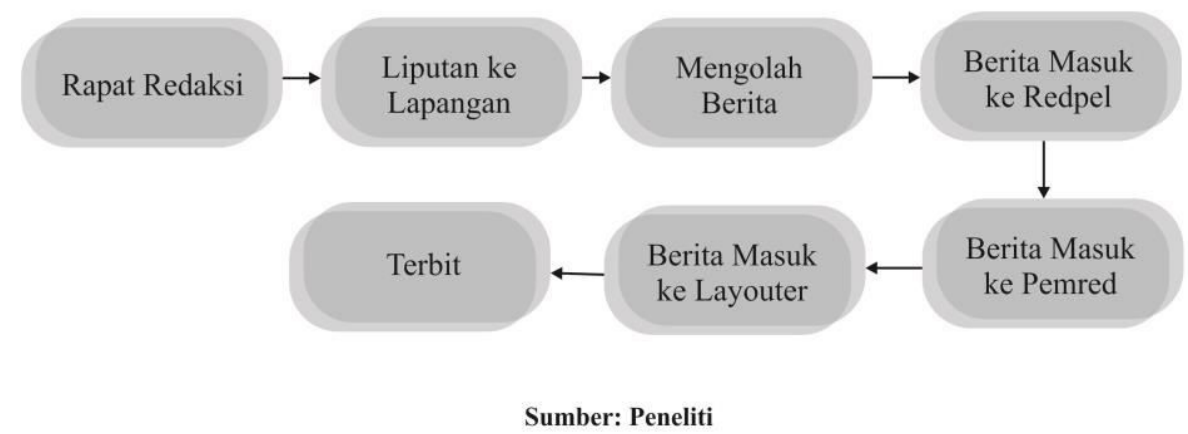

Gambar 2 Alur Manajemen Mangle Sebelum Ada Portal Online

Saat ini terdapat 17 kru redaksi yang bekerja di Mangle, termasuk Pemimpin Redaksi, Wakil Pemimpin Redaksi, Sekretaris Redaksi, Redaktur Pelaksana, dan para kontributor di berbagai daerah di Jawa Barat. Orang-orang pemegang jabatan di Mangle terkadang juga ke lapangan dan menulis berita untuk Mangle cetak. Kualifikasi utama yang dibutuhkan untuk menjadi wartawan Mangle adalah kemampuan berbahasa Sundanya. Karena semua berita ditulis dalam bahasa Sunda, maka kemampuan menulis dan membaca bahasa Sunda diutamakan. Maka, hampir semua kru yang bekerja di redaksi Mangle berlatar belakang pendidikan Sastra Sunda atau Bahasa Sunda.

Organisasi berbasis kekeluargaan yang dipegang Mangle berujung pada pemilihan pemegang jabatan. Seperti Pemimpin Redaksi, Wakil Pemimpin Redaksi, Sekretaris Redaksi dan Redaktur Pelaksana yang kenaikan jabatannya dilakukan secara turun temurun. Ketika pertama kali melakukan penelitian ke Mangle, Ensa Wiarna yang menjadi subjek dari penelitian ini masih berstatus sebagai Wakil Pemimpin Redaksi. Namun 3 bulan kemudian ketika peneliti kembali melakukan wawancara, Ensa Wiarna telah menjadi Pemimpin Redaksi Mangle. Kenaikan jabatan ini dilakukan sebab Tatang Sumarsono selaku Pemimpin Redaksi sebelumnya memutuskan untuk pensiun karena usia.

Setelah kemunculan portal online, alur penyajian berita dalam redaksi Mangle mengalami perubahan. Awalnya, perubahan yang dilakukan tidak begitu signifikan. Namun kemudian Mangle terus mengubah pengelolaan redaksinya karena belum menemukan pengelolaan yang efektif dalam menjalankan media online. 
Setelah 55 tahun mengelola Mangle sebagai majalah mingguan, Mangle kemudian meluncurkan portal dalam jaringan atau online yaitu www.mangleonline.com. Alasan mendasar keluarnya portal online Mangle adalah perkembangan zaman yang semakin canggih dan berubah ke arah digital. Sebagai industri produk informasi yang dinamis, tentunya Mangle perlu ikut beradaptasi dan menyesuaikan dengan kebutuhan pembaca saat ini. Selain untuk mengikuti perkembangan zaman, terdapat pertimbangan lain yang menguatkan terbitnya portal online Mangle ini. Yaitu keinginan untuk memenuhi kebutuhan mitra Mangle yang tidak terjangkau dengan media cetak. Awalnya, portal online Mangle hanya dimaksudkan sebagai alat promosi bagi Mangle cetaknya saja.

\section{Awal Mula Portal Online Mangle}

Mangle online dicetuskan oleh empat orang kru redaksi dari Mangle. Empat orang tersebut adalah Ensa Wiarna, Rudi H. Tarmidzi, Ayi, dan Dadan Sutisna. Persiapan yang dilakukan Mangle tidak banyak. Ketika akhirnya disetujui untuk membuat portal online, Dadan Sutisna sebagai web master langsung membeli hosting dan mendesain situs Mangle online. Awalnya, alamat situs Mangle online yang pertama kali dibuat bukanlah Mangleonline.com seperti sekarang, melainkan majalahmangleonline.com. Penyebab bergantinya alamat situs online Mangle adalah Dadan Sutisna yang memutuskan untuk keluar dari Mangle dan pindah domisili ke Jerman. Karena dalam kru Mangle sendiri tidak ada orang lain yang bisa mengoperasikan situs Mangle, maka awalnya Mangle masih harus bergantung pada web master Dadan Sutisna. Awalnya meski koordinasi dilakukan dalam jarak jauh, konten Mangle online masih bisa diperbarui dan berjalan baik meski pengerjaannya tidak efektif. Sayangnya, tidak berapa lama kemudian, Mangle kehilangan komunikasi dengan Dadan Sutisna, dan portal online Mangle menjadi terabaikan.

Setahun kemudian, Mangle membuat situs baru yang aktif sampai sekarang, yaitu Mangle-online.com. Saat itu, Mangle meminta bantuan Enjang, salah satu kru redaksi Mangle untuk membuat dan mengoperasikan portal Mangle online yang baru ini. Sayangnya Enjang juga kemudian mengundurkan diri dari Mangle. Karena posisi penanggung jawab online tidak ada yang menempati, barulah Mangle mencoba sosialisasi ke dalam kru. Sebelumnya, keempat pencetus Mangle online memang tidak mau melibatkan kru Mangle cetak untuk memegang dan bertanggung jawab atas Mangle online. Sebab, posisi pemegang tanggung jawab online membutuhkan biaya tambahan. Sementara pembuatan portal onlinenya sendiri pun membutuhkan banyak biaya. Modal awal pembuatan Mangle online didapat dari meminjam ke koperasi dan untuk biaya operasional, semuanya ditanggung oleh keempat pencetus Mangle online tersebut. Dengan modal patungan Rp 50.000 setiap minggu, mereka terus mengusahakan agar Mangle online tetap berjalan.

Konten yang ada di Mangle online 80\% sama persis dengan yang ada di cetaknya, dan tentunya sepenuhnya menggunakan bahasa Sunda bahkan dalam software pengupatenya. Selain itu Mangle online juga memberikan beberapa rubrik tambahan sebagai nilai tambah dari portal digitalnya ini. Konsep tersebut membuat Mangle online ketergantungan terhadap Mangle cetak. Sumber konten-konten yang terbit di Mangle online baru dapat diunggah 
10 | Kajian Jurnalisme

ISSN 2549-0559 (cetak) ISSN 2549-1946 (online)

Volume 02 Nomor 01 Tahun 2018

setelah Mangle cetaknya juga terbit. Keberadaan rubrik-rubrik khusus yang hanya ada di online pun akhirnya mengikuti alur terbit Mangle cetak, yaitu seminggu sekali. Seiring berjalannya waktu, Mangle online terkadang menerbitkan pula berita-berita spot news. Karena dari awal tidak ada kesepakatan berapa konten yang harus diterbitkan dalam sehari, maka penerbitan konten online menjadi tidak teratur. Kalau redaksi mau, dan ada kontennya, maka bisa diterbitkan. Tapi kalau tidak ada, maka tidak diusahakan. Keempat pencetus Mangle online tidak melakukan banyak perencanaan dalam membuat portal digital ini. Termasuk tidak adanya penambahan kru karena mereka merasa sanggup mengurus portal online dengan jumlah kru yang ada saat itu.

Setelah melakukan sosialisasi dan mencoba mencari admin dari dalam kru Mangle di luar para pencetus Mangle online, Taufik Rahayu terpilih menjadi penanggung jawab Mangle online. Terpilihnya Taufik sebagai penanggung jawab Mangle online karena Taufik terbilang yang paling melek teknologi di antara kru Mangle online yang lain. Sampai saat ini, Taufik tetap menjadi penanggung jawab portal online meskipun jabatan resminya di Mangle adalah Sekretaris Redaksi.

\section{Wacana Tak Terlaksana}

Alasan utama mengapa awalnya Mangle hanya mengunggah ulang berita yang ada di majalah adalah karena fungsi utamanya yang hanya ingin memberikan akses bagi mereka yang berdomisili di luar Jawa Barat dan luar Indonesia yang tidak bisa mendapatkan majalah Mangle secara fisik. Wakil Pemimpin Redaksi, Rudi H. Tarmidzi mengaku sebenarnya banyak rencana dan wacana dari Mangle online ini yang tidak terlaksana. Meski Rudi menyetujui bahwa desain awal Mangle online hanya untuk memberi akses bagi pembaca Mangle di luar Jawa Barat dan luar Indonesia, tapi setelah beberapa bulan Mangle online berjalan, Rudi lah yang pertama kali menyadari bahwa fungsi portal online lebih dari sekedar media promosi.

Sasaran dari Mangle online sebagai media yang bisa menginformasikan berita-berita Sunda di luar Mangle cetak sampai saat ini belum tercapai. Selain itu, ada pula wacana bahwa sasaran Mangle online sebenarnya adalah digitalisasi. Digitalisasi yang dimaksud Rudi adalah bagaimana majalah Mangle dibuat versi epapernya yang bisa diunduh oleh para pembaca dengan sistem berbayar. Sayangnya, banyak hambatan yang dialami Mangle sehingga wacana ini tak juga terlaksana. Rudi juga memiliki keinginan Mangle online menerapkan sistem konvergensi. Meski mengatakan demikian, Rudi tidak menyadari bahwa sebenarnya Mangle online sudah melakukan sistem konvergensi untuk konten, teknologi dan bisnis meski semuanya belum berjalan sempurna.

\section{Adaptasi Mangle Terhadap Mangle Online}

Berikut adalah bagan alur kerja redaksi Mangle setelah mengeluarkan portal online: 
ISSN 2549-0559 (cetak) ISSN 2549-1946 (online)

Volume 02 Nomor 01 Tahun 2018

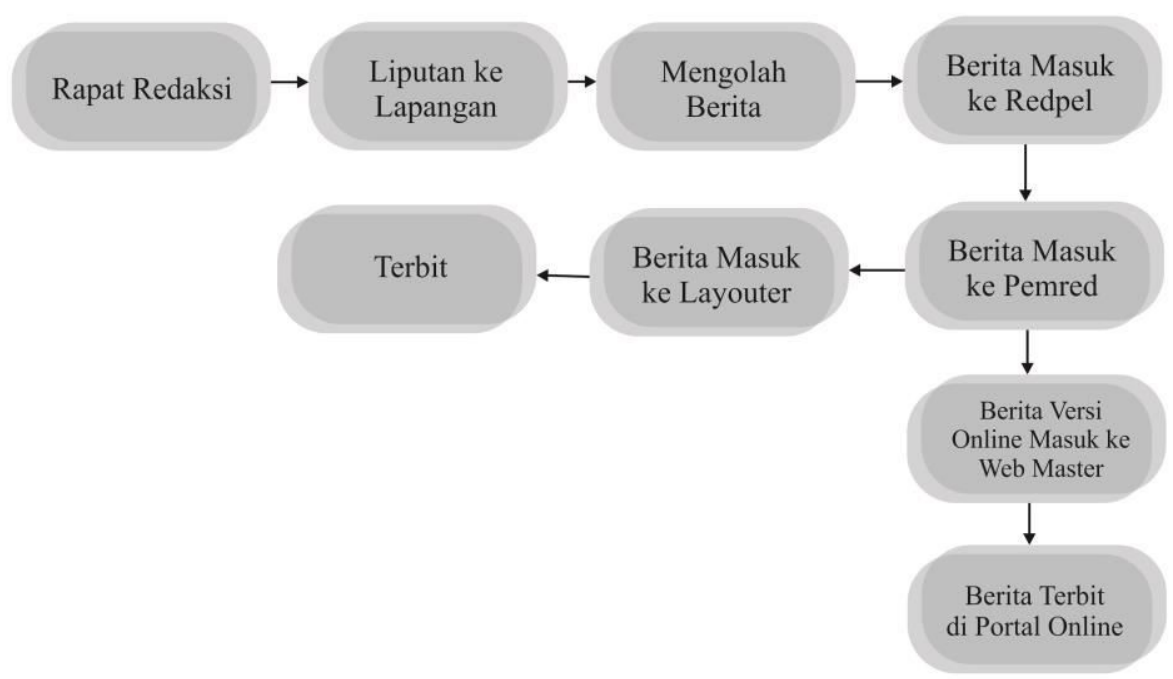

Gambar 3 Bagan Alur Manajemen Mangle Setelah Ada Portal Online Sumber: Olahan Peneliti

Sebagaimana mengerjakan majalah cetaknya, produksi berita-berita yang disajikan di Mangle online diawali dengan rapat redaksi setiap Kamis siang di kantor redaksi Mangle. Setelah menyetujui topik dan membagi tugas, sama seperti mengerjakan majalah cetak, wartawan mulai ke lapangan untuk mencari berita. Berita kemudian masuk ke redaktur pelaksana untuk melakukan pengecekan konten dan tulisan. Setelah itu, redaktur pelaksana memberikan berita yang telah diedit ke pemimpin redaksi untuk dicek kembali sebelum diberikan ke layouter untuk dicetak. Perbedaan signifikan terdapat pada peran pemimpin redaksi yang setelah mengedit tidak hanya memberikan tulisan ke layouter, tapi juga memberikan berita kepada web master untuk menggunggahnya ke versi online. Di sini pemimpin redaksi juga perlu bekerja dua kali dalam mengedit. Sebab editan untuk portal online harus disesuaikan dengan bahasa jurnalisme online.

Alur kerja redaksi seperti ini hanya berlaku pada rubrik-rubrik yang ada di cetak maupun onlinenya. Sementara portal online Mangle juga memiliki beberapa rubrik khusus. Berikut adalah bagan alur kerja redaksi untuk rubrik-rubrik yang hanya ada di portal online:

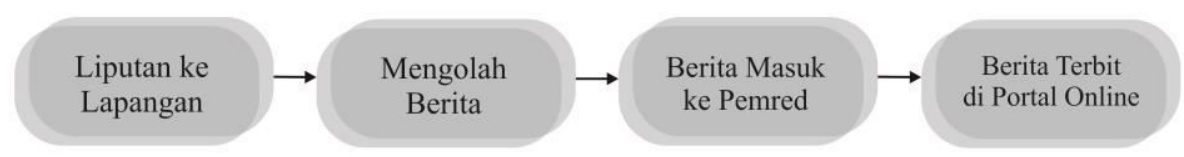

Gambar 4 Bagan Alur Manajemen Mangle Khusus Rubrik di Portal Online Sumber: Olahan Peneliti

Mengerjakan rubrik-rubrik khusus yang hanya ada di portal online Mangle tidak pernah melewati proses rapat redaksi. Karena tidak ada pula wartawan yang dikhususkan untuk meliput dan mengisi rubrik-rubrik yang hanya ada di online, maka pengisian kontennya 
12 | Kajian Jurnalisme

ISSN 2549-0559 (cetak) ISSN 2549-1946 (online)

Volume 02 Nomor 01 Tahun 2018

dilakukan hanya bila ada konten yang bisa diliput atau ada kru yang inisiatif mau mengisi rubrik-rubrik tersebut. Sayangnya, jarang sekali ada wartawan yang mau inisiatif mengisi rubrik tersebut, sehingga biasanya hanya Pemimpin Redaksi Ensa Wiarna, Wakil Pemimpin Redaksi Rudi H. Tarmidzi lah yang biasanya mengisi rubrik tersebut.

\section{Portal Online Setelah Pergantian Manajemen}

Ketika kemudian Enjang mengundurkan diri dari Mangle dan menarik Taufik sebagai penanggung jawab online, alur kerja redaksi Mangle kemudian ikut berubah. Semua wartawan mulai diberikan sosialisasi bahwa mereka bisa menulis konten untuk portal online dan bahkan bisa mengunggahnya sendiri. Berikut alur kerja redaksi Mangle setelah Taufik menjadi penanggung jawabnya:

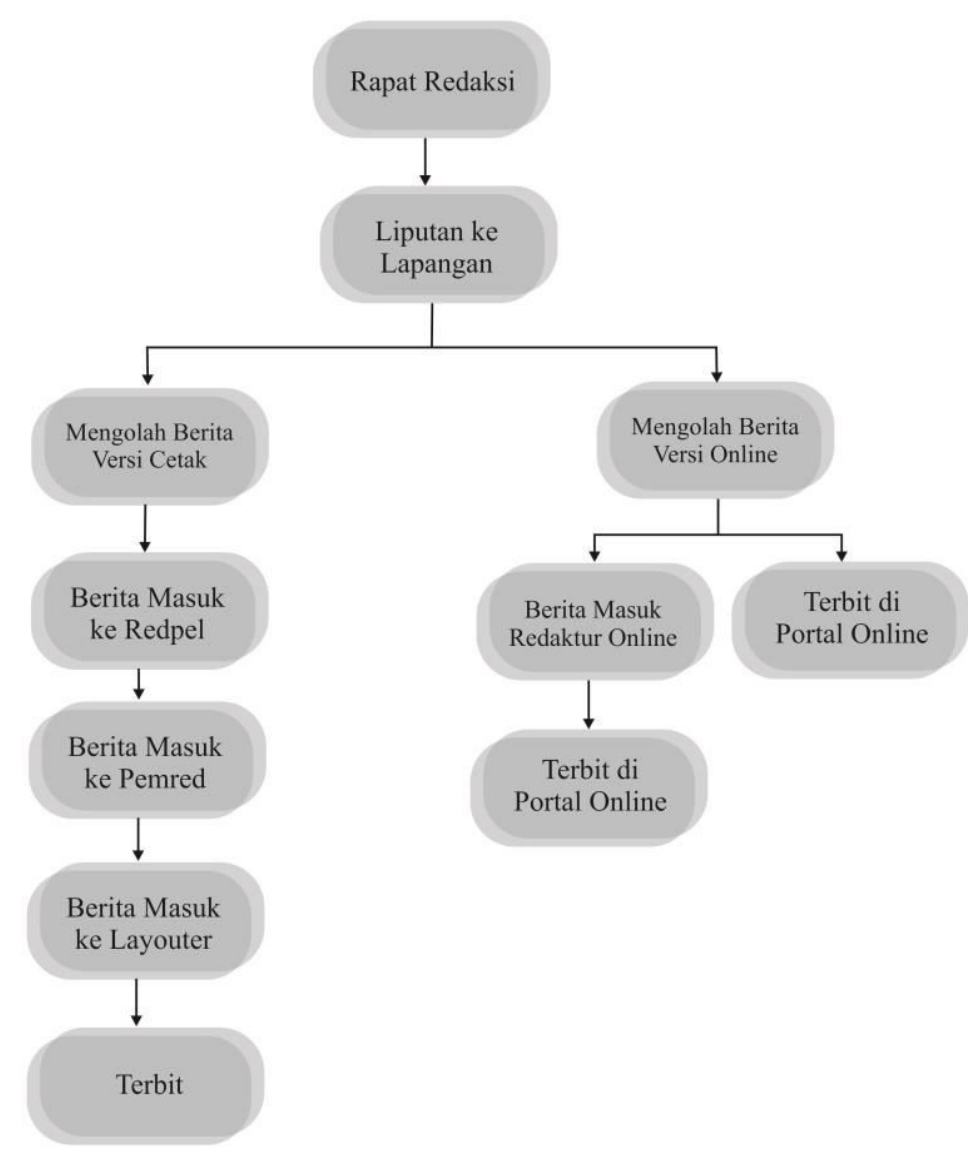

Gambar 5 Bagan Alur Manajemen Mangle Online Saat Ini

Sumber: Peneliti

Taufik sebagai penanggung jawab Mangle online diberikan kebebasan untuk mengunggah konten-konten ke portal online tanpa perlu mendapat persetujuan Pemimpin Redaksi. Karenanya, setelah berita versi online selesai ditulis oleh wartawan, mereka bisa langsung mengirim ke Redaktur Online dan bisa setelahnya segera diunggah ke portal online. Bahkan wartawan sendiri sudah diberi keleluasaan untuk mengunggah sendiri berita mereka 
ke portal online tanpa melalui proses editing dari Redaktur Online maupun Pemimpin Redaksi. Setiap wartawan telah diberi informasi mengenai tata cara mengunggah berita ke portal online, sehingga mereka bisa melakukannya sendiri. Meski memiliki alur yang cukup sederhana dan terbilang cukup cepat, wartawan Mangle rupanya jarang memiliki inisiatif untuk mengisi konten online. Kalaupun ada, kebanyakan akan mengirim ke Redaktur Online terlebih dulu sehingga Redaktur Online yang akan mengunggahnya ke portal online.

\section{Hambatan yang Dihadapi Mangle}

\section{Kru Redaksi}

Saat ini kru redaksi yang bekerja di Mangle ada 17 orang, termasuk para pemegang jabatan. Jumlah ini awalnya dirasa cukup untuk mengelola Mangle online dan cetaknya sekaligus. Sebab kebutuhan awal dari konten Mangle yang akan masuk ke portal onlinenya adalah konten yang sama yang akan masuk ke Mangle cetak. Kru yang ada hanya mendapat tambahan tugas untuk membuat dua versi tulisan dengan konten yang sama. Waktu pengerjaan yang diberikan juga sama dengan Mangle cetak, sebab penerbitan tulisan di Mangle online dilakukan bersamaan dengan Mangle cetak. Karena beban kerja tambahan yang diberikan pada kru redaksi tidak begitu berat, maka para pencetus awal Mangle online merasa kebutuhan akan penambahan kru tidak diperlukan. Pengerjaan Mangle online yang kemudian berbeda dari rencana awalnya, menjadikan penambahan kru dibutuhkan. Mangle online yang kemudian menyajikan rubrik lain di luar Mangle cetak serta ruang untuk menyajikan spot news dalam bahasa Sunda menimbulkan penambahan beban kerja yang cukup banyak bagi para wartawan Mangle yang juga fokus mengerjakan cetaknya.

Rudi mengatakan bahwa meskipun terlihat mudah, pengoperasian Mangle online rupanya tidak semudah itu. Perlu orang-orang yang fokus mengerjakan Mangle online tanpa terganggu beban kerja lain di redaksi. Wartawan Mangle sendiri pun tidak merasa memiliki tanggung jawab terhadap Mangle online. Mereka merasa keberadaan Mangle online tidak begitu signifikan sehingga kebanyakan memilih untuk melanjutkan pekerjaan dan kewajiban mereka yang biasa, yaitu mengisi Mangle cetaknya saja.

Selain hambatan dari segi jumlah, rupanya Mangle juga mengalami hambatan dari segi kemampuan yang dimiliki kru Mangle. Taufik Rahayu yang kini diangkat sebagai pemegang tanggung jawab di Mangle online pun tidak memiliki dasar kemampuan dalam bidang teknologi. Setelah resmi menjadi penanggung jawab online pun ia tidak diberi pelatihan khusus atau pembelajaran formal mengenai media online baik secara teori maupun teknis. Karena mempelajari segalanya secara otodidak, maka kemampuan kru redaksi dalam mengelola portal online pun tidak berjalan dengan begitu lancar. Sebab, apa yang harus dipelajari kru redaksi bukan hanya penulisan dalam gaya online yang sesederhana dibuat pendek, tapi juga dalam mengelola online seharusnya dipahami mengenai desain tampilan, masalah hosting, programmer dan software-software pendukungnya. 
14 | Kajian Jurnalisme

ISSN 2549-0559 (cetak) ISSN 2549-1946 (online)

Volume 02 Nomor 01 Tahun 2018

\section{Konten Khusus Mangle Online}

Mangle membuat rubrik-rubrik yang tidak ada di Mangle cetak serta mulai memasukkan berita-berita langsung yang disajikan dalam bahasa Sunda. Sayangnya, konten-konten untuk rubrik-rubrik khusus ini tidak berjalan seperti yang diharapkan. Hambatannya adalah tidak adanya target konten dan materi yang ditetapkan setiap harinya. Bahkan tidak juga menetapkan target konten per minggu, mengikuti terbitnya majalah Mangle cetak.

\section{Teknologi Pendukung}

Mengelola portal online membutuhkan bukan hanya kru yang mengerti cara pengoperasian teknologi tapi juga alat-alat pendukungnya. Hambatan lain yang dialami Mangle dalam mengoperasikan portal online adalah tidak adanya dana yang dialokasikan untuk mengakomodasi keperluan alat teknologi yang dibutuhkan. Selain masalah koneksi, alat pendukung untuk mengunggah berita pun belum tersedia di Mangle. Keinginan Rudi adalah memiliki satu komputer atau tablet PC khusus untuk operasional Mangle online. Menurutnya dengan alat yang dikhususkan akan membantu pengelolaan Mangle online agar fokus.

\section{Strategi Manajemen Redaksi Mangle}

Sejak awal kemunculannya, Mangle online memang memiliki berbagai kekurangan. Karenanya, saat ini Rudi dan Ensa sebagai dua pencetus Mangle online yang masih tersisa saat ini akan menggalakkan kembali pengelolaan Mangle online. Sasaran yang ditetapkan adalah bagaimana Mangle online bisa berjalan sebagaimana sifat media online yang cepat. Bukan hanya menjalankan kembali websitenya, tapi juga mengaktifkan Mangle versi e-paper dan bahkan membuat Mangle TV yang bisa distreaming oleh pembaca Mangle di saluran YouTube milik Mangle.

Memilki pengalaman dengan hambatan dan kegagalan sebelumnya, saat ini Rudi pun mulai melangkah dengan hati-hati. Rudi sudah mulai mempersiapkan rencana-rencana agar mencapai target sasaran Mangle online yang baru. Yaitu menjadi media online profesional yang selalu up to date setiap rubriknya dengan rutin dan cepat. Perencanaan ulang ini dilakukan oleh Rudi H. Tarmidzi yang sekarang menjabat sebagai Wakil Pemimpin Redaksi bersama dengan Taufik Rahayu yang sekarang menjabat sebagai Sekretaris Redaksi sekaligus admin online. Perencanaan pengelolaan portal online yang saat ini digarap dominannya berfokus pada perekrutan dan pengembangan SDM. Meski begitu, perencanaan pengembangan sarana dan konten juga tidak luput dari perhatian.

Telah diakui oleh para kru redaksi bahwa kurangnya jumlah kru serta kemampuan yang dimiliki kru saat ini adalah hambatan terbesar yang dialami Mangle dalam mengelola portal onlinenya. Karenanya langkah awal yang diambil oleh Mangle adalah perencanaan dalam hal kru redaksi. Rudi H. Tarmidzi sebagai pencetus awal Mangle online mengatakan bahwa dalam mengatasi hambatan yang dialami dari segi kru redaksi terdapat dua pilihan. Pertama adalah perekrutan kru baru sebagai tenaga sumber daya tambahan yang dikhususkan untuk menulis di portal online. Pilihan kedua adalah meningkatkan kemampuan kru redaksi 
yang dimiliki saat ini dalam bidang teknologi informasi dan pengoperasian peranti lunak yang dibutuhkan untuk mengunggah konten ke portal online.

Pada perencanaan Mangle online sebelumnya, konten yang dimasukkan adalah konten yang sama dengan yang ada di majalah cetaknya. Sementara dalam strategi perencanaan pengelolaan Mangle online yang sekarang sedang digarap kembali oleh Mangle, kontenkonten dalam rubrik yang hanya ada di online akan lebih difokuskan.

Langkah ideal yang direncanakan Mangle dalam pengumpulan bahan konten untuk rubrik-rubrik khusus tersebut adalah, pertama melakukan riset dan diskusi singkat untuk penentuan topik konten per rubrik. Selanjutnya, bahan dicari ke lapangan lalu diolah sampai siap terbit. Untuk pengolahan bahan-bahan konten masih harus dilakukan di kantor terutama untuk foto. Sebab pengeditan foto memerlukan peranti lunak pendukung dan tidak memungkinkan bila hanya lewat ponsel pribadi wartawan. Foto pun disesuaikan dengan tampilan online yang cukup berbeda dengan cetaknya yang memiliki standar hitam putih. Konten-konten tersebut kemudian dikirim ke admin online untuk diedit kemudian diterbitkan di portal onlinenya. Bila digambarkan dalam bagan, maka perencanaan alur kerja redaksi Mangle online sebagai berikut:

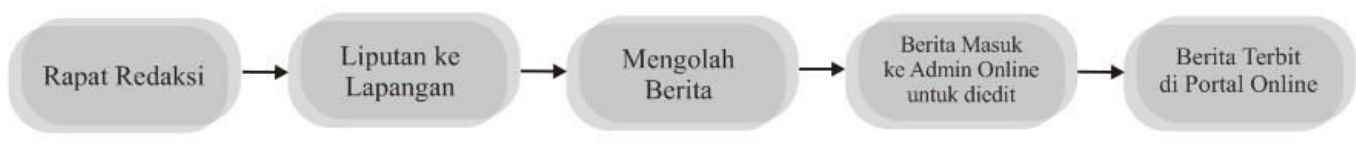

Gambar 6 Bagan Strategi Alur Manajemen Mangle Online

Sumber: Olahan Peneliti

Rapat redaksi dilakukan hanya oleh wartawan yang memang bertanggung jawab menulis di online bersama dengan penanggung jawab portal online. Standar konten serta sudut pandang yang dipakai di setiap tulisan akan berbeda dari yang ada di Mangle cetak, meskipun masih menggungkan basis budaya dan bahasa Sunda. Karena jangakuan dari portal online sendiri cukup luas, maka redaksi Mangle memutuskan bahwa konten-konten yang disajikan di portal online juga disesuaikan dengan para pembacanya yang beragam. Tujuan utama dari penyajian kontennya adalah bagaimana dengan konten-konten tersebut Mangle bisa dianggap sebagai rumah besar orang-orang Sunda di dunia.

Sebagus apapun naskah yang dibuat oleh para kru Mangle, tentunya akan menjadi percuma bila fasilitas yang disediakan tidak memadai. Maka Mangle pun menyiapkan daftar teknologi pendukung yang dapat membantu kelancaran pengelolaan manajemen redaksi portal online yang saat ini kembali Mangle garap. Terdapat beberapa fasilitas yang saat ini telah Mangle miliki sebagai teknologi pendukung manajemen portal Mangle online. Salah satunya adalah program pengunggah konten ke website Mangle yang dibeli dari administrator. Selain itu Mangle juga telah memiliki peranti lunak Adobe Photoshop yang digunakan untuk mengedit foto. Sementara itu, beberapa teknologi pendukung tambahan yang ingin dimiliki 
16 | Kajian Jurnalisme

ISSN 2549-0559 (cetak) ISSN 2549-1946 (online)

Volume 02 Nomor 01 Tahun 2018

Mangle untuk mendukung keefektifan pengelolaan portal online ini adalah adanya tablet PC khusus untuk mengelola media sosial Mangle. Selain itu juga komputer khusus yang digunakan penanggung jawab Mangle online untuk mengunggah dan mengedit berita. Rudi juga berharap adanya pengalokasian dana untuk biaya kuota wartawan Mangle agar mereka bisa mengirim berita langsung dari lapangan, terutama untuk berita-berita peristiwa atau spot news.

\section{Pembahasan Penerapan Fungsi Manajemen di Redaksi Mangle Online}

Seperti yang dikatakan T. Hani Handoko (dalam Morissan, 2008:135), manajemen dibutuhkan oleh semua organisasi, sebab tanpa manajemen semua usaha yang dilakukan organisasi akan sia-sia dan pencapaian tujuan akan menjadi lebih sulit.

Begitu juga dengan Mangle sebagai salah satu organisasi industri media yang saat ini masih berjalan dan menerapkan fungsinya sebagai media massa. Menurut George R. Terry, dalam menjalankan manajemen dalam suatu organisasi, terdapat empat fungsi yang diterapkan yaitu, perencenaan (planning), pengorganisasian (organizing), pelaksanaan (actuating) dan pengawasan (controlling). Keempat fungsi ini harus berjalan agar sebuah organisasi dapat dikelola dengan baik.

Dalam mengelola Mangle cetak sebelum munculnya Mangle online juga menerapkan keempat fungsi ini pada divisi redaksinya. Bila dibuat bagan, seperti inilah cara Mangle cetak menjalankan keempat fungsi manajemen tersebut.

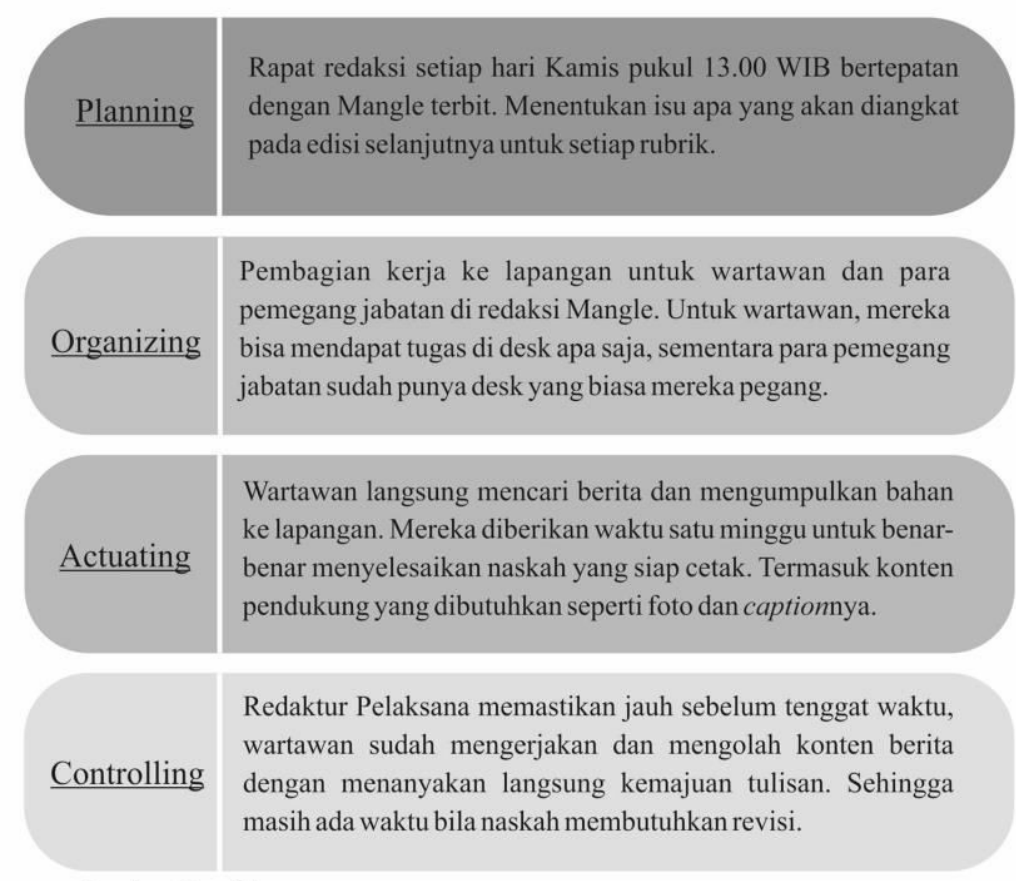

Gambar 7 Bagan Pemetaan Fungsi Manajemen George R. Terry di Redaksi Mangle Cetak Sumber: Olahan Peneliti 
Pada tahun 2012, Mangle memunculkan portal online dan terdapat perubahan dalam manajamen redaksi Mangle. Maka, otomatis penerapan keempat fungsi manajemen yang sebelumnya dilakukan Mangle pun ikut berubah.

\section{Fungsi Perencanaan}

Suwadi Sutono (2003) mengatakan bahwa proses awal manajemen media massa yang paling menentukan adalah pada tahap perencanaan. Karena dalam tahap perencanaan ditentukan latar belakang dibuatnya produk media termasuk idealisme, filosofi serta visi dan misinya. Selain itu, tahap ini juga adalah tahap menentukan tujuan, penentuan strategi, kebijakan, program, proyek, prosedur, sistem, metode, anggaran termasuk standar yang dibutuhkan untuk mencapai tujuan. (Fayol, 1949). Intinya, perencanaan adalah pondasi awal yang menentukan arah manajemen agar berjalan dengan baik.

George R. Terry (dalam Purwanto, 2012: 48) mengatakan perencaan adalah memilih dan menguhubungkan fakta dan membuat serta menggunakan asumsiasumsi mengenai masa yang akan datang dengan jalan menggambarkan dan merumuskan kegiatan-kegiatan yang diperlukan untuk mencapai hasil yang diinginkan. Sudah menjadi tugas seorang manajer untuk menentukan keputusan akan tujuan, kebijakan, prosedur, program dan alternatif yang baik.

Terdapat beberapa langkah yang bisa diterapkan manajer dalam melakukan perencanaan (Purwanto, 2012: 53): 1) Menjelaskan serta merumuskan dahulu masalah/usaha/tujuan yang akan direncanakan itu; 2) Mengumpulkan data, informasi dan fakta yang diperlukan secukupnya; 3) Menganalisa dan mengklarifikasi informasi serta hubungan-hubungannya; 4) Menetapkan perencanaan, premis-premis dan hambatanhambatan serta hal-hal yang mendorongnya; 5) Menentukan beberapa alternatif; 6) Pemilihan keputusan yang terbaik dari dari alternatif-alternatif yang ada; 7) Tetapkanlah urutan-urutan dan penetapan waktu secara terperinci bagi rencana yang diusulkan. 8) Laksanakan pengecekan tentang kemajuan rencana yang diusulkan. Dari beberapa langkah penetapan perencanaan yang disebutkan Purwanto, Mangle telah melakukannya dalam perencanaan pembuatan Mangle online. Mulai dari awal dimana mereka merumuskan masalah, usaha dan tujuan dari dibuatnya portal digital Mangle tersebut. Saat melakukan perencanaan, beberapa pemegang jabatan di Mangle berkumpul dan mendiskusikannya bersama.

Langkah selanjutnya adalah mengumpulkan data, informasi dan fakta yang diperlukan secukupnya yang kemudian dianalisa dan diklarifikasi. Dalam tahap ini, pengumpulan data dan informasi yang dilakukan Mangle hanyalah kenyataaan bahwa cukup banyak orang Sunda di luar Indonesia yang ingin membaca Mangle namun tidak memiliki akses. Ketika mengeluarkan portal online, para pencetus Mangle online sama sekali tidak mencari informasi dan pengetahuan mengenai media online, baik cara pengelolaan maupun sifat-sifatnya yang tentu jauh berbeda dari media cetak. Hanya berdasarkan informasi itu, Mangle memutuskan untuk membuat portal online dan menyediakan jalan akses baru untuk membaca online.

Kegagalan dalam perencanaan bisa menyebabkan kegagalan dalam keseluruhan manajemen. Karena pelaksanaan manajemen bergantung pada baik atau buruknya suatu rencana. 
18 | Kajian Jurnalisme

ISSN 2549-0559 (cetak) ISSN 2549-1946 (online)

Volume 02 Nomor 01 Tahun 2018

Hal ini kemudian dirasakan sendiri oleh Mangle yang setelah 2 tahun berjalan menyadari informasi lain yang mempengaruhi perencanaannya. Fakta yang diketahui belakangan oleh pencetus Mangle online adalah terdapat bentuk lain penyajian konten dalam jaringan selain melalui laman website yaitu dengan bentuk e-paper. Bila melihat fungsi epaper yang bisa dijual lewat portal digital, tentunya penyajian konten jenis ini bisa langsung memenuhi tujuan utama Mangle yang mau memberi akses bagi pembaca di luar Indonesia. Namun, karena perencanaan sudah ditetapkan dengan membuat laman website, maka tujuan utamanya pun diubah menjadi upaya Mangle dalam mengikuti dan beradaptasi dengan perubahan zaman

Selanjutnya, menetapkan perencanaan, premis dan hambatan. Dalam menetapkan perencanaan, manajer harus bisa menetapkan sasaran yang jelas akan menjadi seperti apa program perencanaannya. Penetapan premis juga termasuk prosedur kegiatan, biaya yang perlukan, penjadwalan yang seimbang, serta penafsiran kebijakan. Hal ini lah yang tidak masuk dalam tahap perencanaan yang dilakukan Mangle. Mangle juga tidak membuat alternatif lain dalam perencanaannya sehingga tidak bisa juga melakukan langkah selanjutnya yaitu memilih keputusan dari alternatif yang ada

\section{Fungsi Organisasional}

George Terry (dalam Sukarna, 2010: 38) menjelaskan bahwa pengorganisasian ialah penentuan, pengelompokkan, dan penyusunan macam-macam kegiatan yang diperlukan untuk mencapai tujuan, penempatan orang-orang (pegawai), terhadap kegiatan-kegiatan ini, penyediaan faktor-faktor fisik yang cocok bagi keperluan kerja dan penunjukkan hubungan wewenang, yang dilimpahkan terhadap setiap orang dalam hubungannya dengan pelaksanaan setiap kegiatan yang diharapkan.

Ketika awal Mangle memutuskan untuk mengeluarkan portal online, kru Mangle tidak melakukan pengelompokan dan penyusunan kegiatan yang diperlukan. Mangle juga tidak mengubah penempatan pegawai dan melimpahkan wewenang baru pada krunya. Pada dasarnya, bila menyesuaikannya dengan definisi pengorganisasian yang dijelaskan Terry, dapat dibilang bahwa Mangle sama sekali tidak melakukan pengorganisasian terhadap redaksi Mangle online.

\section{Fungsi Pergerakan}

Morissan (2008: 162) mengubah kata pelaksanaan menggunakan pengarahan dan memberikan pengaruh agar lebih spesifik. Penggerakan adalah upaya untuk membuat semua anggota organisasi agar mau bekerja sama untuk mencapai tujuan sesuai dengan perencanaan dan usaha-usaha pengorganisasian. Morissan mengungkapkan bahwa kegiatan mengarahkan dan memberikan pengaruh ini mencakup empat kegiatan penting yaitu pemberian, motivasi, komunikasi, kepemimpinan dan pelatihan.

Mangle online dalam pelaksanaannya tidak melakukan apa pun untuk merangsang motivasi kru. Karena pertama Mangle tidak mengikutsertakan kru redaksi secara keseluruhan dari awal untuk ikut serta dalam mengurus Mangle online ini. Kedua, tidak ada pula komunikasi terutama yang formal soal pembuatan Mangle online yang menunjukkan keseriusan pembentukan Mangle online ini. Terakhir, tidak ada pula perhatian timbal balik 
setelah wewenang di delegasikan. Akhirnya kru Mangle tidak memiliki motivaasi khusus dalam mengerjakan Mangle online dan tetap fokus pada cetaknya. Mangle juga tidak memberikan kru redaksinya pelatihan yang bisa mengembangkan kemampuan para kru. Tidak ada pula pelatihan yang berkaitan langsung dengan jurnalisme online ketika Mangle hendak mengeluarkan portal online. Pada pelaksanaan fungsi penggerakkan Terry (dalam Sukarna, 2010: 82-83) mengatakan bahwa perencanaan dan pengorganisasian merupakan landasan yang kuat untuk adanya penggerakan yang terarah kepada sasaran yang dituju. Maka, berdasarkan pernyataan Terry tersebut, penggerakan Mangle online pun belum bisa dibilang efektif karena perencanaan dan pengorganisasian sebagai pondasinya juga tidak kuat.

\section{Fungsi Pengawasan}

Purwanto (2012: 73) menjelaskan bahwa proses pengendalian dilakukan melalui beberapa tahap meliputi: menentukan standar-standar atau dasar untuk kontrol, mengatur pelaksanaan, membandingkan pelaksanaan dengan standar dan menentukan deviasi-deviasi (penyimpangan) bila ada, dan menentukan tindakan perbaikan jika terdapat penyimpangan agar pelaksanaan dan tujuan sesuai dengan rencana.

Standar yang ditentukan Mangle dalam pengelolaan portal online nya adalah bagaimana setidaknya Mangle bisa tetap memperbarui konten online bersamaan dengan terbitnya majalah. Untuk pengendalian pasca perubahan sasaran dalam pengelolaan Mangle online, standarnya belum dilakukan karena perencanaan dan pengorganisasiannya sendiri belum matang. Sementara menurut Purwanto (2012: 72) pengendalian itu harus ditujukan ke arah tercapainya tujuan dan menghindari penyimpangan-penyimpangan dari rencana. Maka bila arah tujuannya belum jelas, pengendalian tidak mungkin dilakukan.

Tahap selanjutnya adalah mengatur pelaksanaan dan menentukan deviasi bila ada. Deviasi yang terjadi adalah tidak terlaksananya pembaruan konten online bersamaan dengan waktu terbit Mangle cetak. Karena sempat beberapa kali ketika Mangle cetak terbit, namun konten di Mangle online tidak ikut diperbarui. Tahap terakhir adalah menentukan tindakan perbaikan pada penyimpangan agar pelaksanaan sesuai dengan rencana. Namun, Mangle juga tidak melaksanakan tahap ini karena ketika deviasi ini terjadi, Mangle tidak kemudian mengunggah edisi tersebut dan hanya akan mengunggah edisi selanjutnya saja minggu depan sambil memastikan hal ini tidak terulang kembali.

Setelah menganalisis satu per satu keempat fungsi manajemen yang dilakukan Mangle dalam mengelola portal online nya, maka bila dibuat bagan, seperti inilah cara Mangle online menjalankan keempat fungsi manajemen tersebut: 
20 | Kajian Jurnalisme

ISSN 2549-0559 (cetak) ISSN 2549-1946 (online)

Volume 02 Nomor 01 Tahun 2018

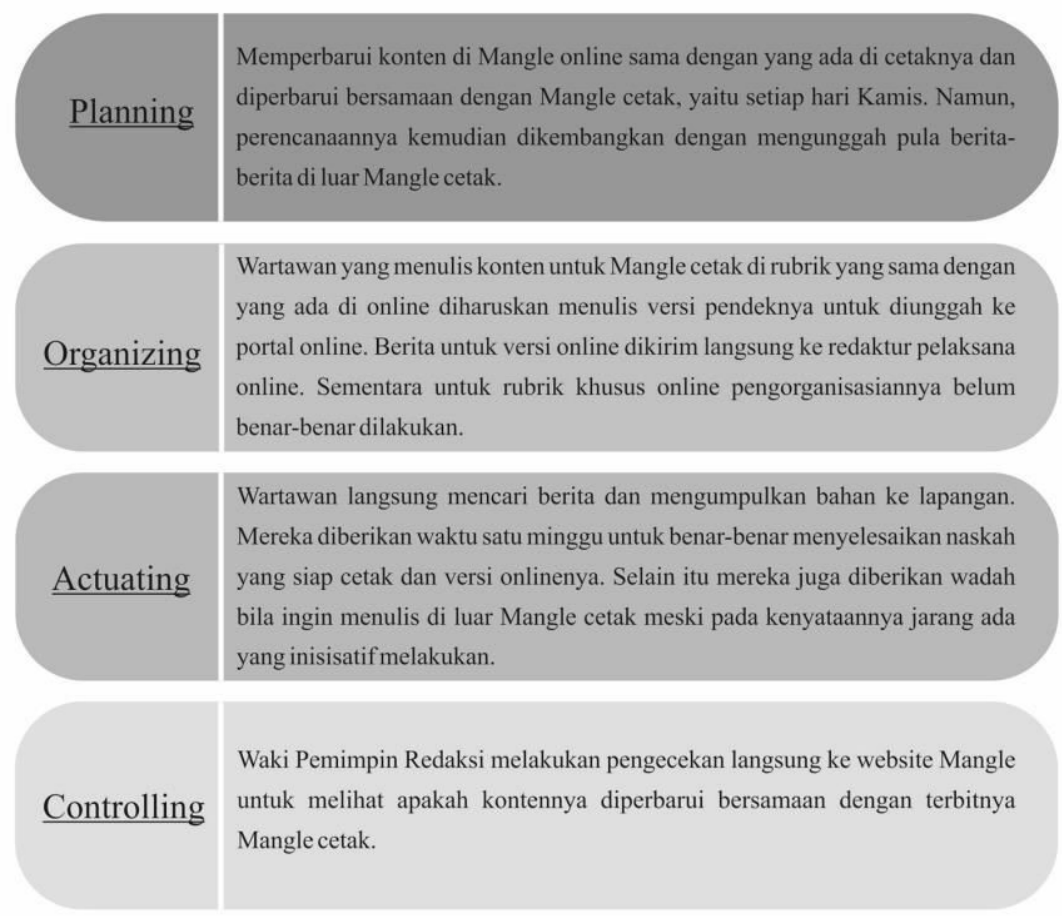

Gambar 8 Bagan Pemetaan Fungsi Manajemen George R. Terry di Redaksi Mangle Online

Sumber: Olahan Peneliti

\section{Stragegi Manajemen Redaksi}

Ketika membuat Mangle online serta sasaran-sasaran yang menjadi tujuannya, para pencetusnya tentu telah membuat rencana rangka panjang untuk keberlangsungan hidup Mangle online. Rencana-rencana Mangle ini lah yang akan peneliti analisis menggunakan pendekatan value chain dari Michael E. Porter. Menurut Porter, pendekatan ini memandang perusahaan sebagai suatu rangkaian atau jaringan aktivitas dasar yang menambah niliai bagi produk atau jasanya. Value chain membicarakan soal proses pembuatan produk (dalam penelitian ini produk media yaitu berita) sejak nilai asli sampai hasil jadi, dengan aktivitasaktivitas yang dapat dibagi-bagi dan lebih efisien.

Analisis value chain dari Porter fokus kepada dua aktivitas utama dalam pengelolaan strategi manajemen yaitu primary activities dan supporting activities. Primary activities mencakup inbound logistic, operations, outbound logistics, marketing and sales, dan services. Sedangkan supporting activities mencakup procurement, technology developement, human resource management, dan firm infrastructure.

Peneliti selanjutnya akan menggunakan model konseptual Maturity Level pada pendekatan ini untuk menganalisis level manajemen strategi yang diterapkan Mangle pada portal onlinenya sebagai upaya beradaptasi di era digital. Berdasarkan model konseptual tersebut, dapat dibuat satu matriks penilaian dengan level maturity sebagai berikut: (1) skor 0 jika tidak ada aktivitas; (2) skor 1 - undefined - telah ada aktivitas, namun belum terdokumentasi dan tidak terstandarisasi; (3) skor 2 - defined - aktivitas mulai dilakukan 
secara berulang; (4) skor 3 - manageable - aktivitas telah terstandar dan konsisten serta terukur; (5) skor 4 - collaborative - aktivitas telah mengalami kolaborasi dengan pihak luar; (5) skor 5 - leading - aktivitas yang terkolaborasi dengan supplier dan customer telah dievaluasi secara periodik untuk pengembangan.

Dari hasil analisis data yang terkumpul, maka maturity level dari setiap aktivitas dalam pendekatan value chain dapat dilihat pada tabel berikut:

Tabel 1 Analisis Strategi Manajemen Mangle menggunakan Value Chain Michael Porter

\begin{tabular}{|c|c|c|c|}
\hline & & & $\begin{array}{l}\text { Maturity } \\
\text { Level }\end{array}$ \\
\hline \multirow{13}{*}{ 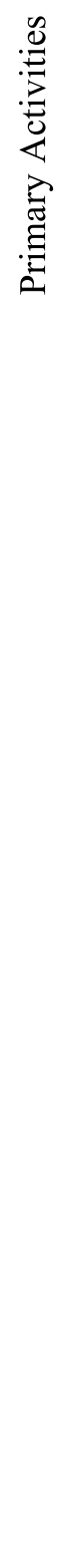 } & \multirow{4}{*}{ Inbound Logistic } & $\begin{array}{c}\text { Perencanaan topik dan riset awal } \\
\text { konten berita }\end{array}$ & 3 \\
\hline & & $\begin{array}{l}\text { Penentuan narasumber, sudut pandang } \\
\text { pemberitaan dan } \\
\text { pembagian kerja untuk wartawan } \\
\text { ke lapangan }\end{array}$ & 3 \\
\hline & & $\begin{array}{c}\text { Pengolahan konten menjadi naskah siap } \\
\text { terbit }\end{array}$ & 4 \\
\hline & & $\begin{array}{l}\text { Penerimaan konten berita (naskah } \\
\& \text { foto) siap terbit oleh Redaktur } \\
\text { Pelaksana Online }\end{array}$ & 3 \\
\hline & \multirow{3}{*}{ Operation } & $\begin{array}{l}\text { Pengumpulan naskah siap terbit oleh } \\
\text { Redaktur Pelaksana Online }\end{array}$ & 3 \\
\hline & & $\begin{array}{l}\text { Pengecekan kembali kontenkonten } \\
\text { naskah secara menyeluruh }\end{array}$ & 2 \\
\hline & & Pengeditan naskah bila ada kesalahan & 2 \\
\hline & \multirow{3}{*}{ Outbound Logistic } & $\begin{array}{l}\text { Pengumpulan kembali naskah yang } \\
\text { sudah dicek dan diedit }\end{array}$ & 3 \\
\hline & & $\begin{array}{l}\text { Pengunggahan naskah-naskah yang } \\
\text { sudah dikumpulkan ke portal } \\
\text { online }\end{array}$ & 2 \\
\hline & & $\begin{array}{l}\text { Penyimpanan naskah yang sudah } \\
\text { diterbitkan untuk arsip }\end{array}$ & 2 \\
\hline & \multirow{3}{*}{ Marketing and Sales } & $\begin{array}{l}\text { Promosi pemberitahuan terbitnya } \\
\text { tulisan baru pada website Mangle di } \\
\text { akun media sosial yang dimiliki } \\
\text { Mangle }\end{array}$ & 4 \\
\hline & & $\begin{array}{l}\text { Menyertakan link ke berita yang } \\
\text { bersangkutan di postingan pada akun } \\
\text { media sosial Mangle }\end{array}$ & 4 \\
\hline & & Menuliskan iklan promosi di & 0 \\
\hline
\end{tabular}


22 | Kajian Jurnalisme

ISSN 2549-0559 (cetak) ISSN 2549-1946 (online)

Volume 02 Nomor 01 Tahun 2018

\begin{tabular}{|c|c|c|c|}
\hline & & $\begin{array}{l}\text { Mangle cetak untuk mengunjungi } \\
\text { laman Mangle online }\end{array}$ & \\
\hline & & $\begin{array}{l}\text { Menyediakan jenis konten yang } \\
\text { beragam di laman website Mangle }\end{array}$ & 0 \\
\hline & Services & $\begin{array}{l}\text { Penyesuaian sudut pandang dan } \\
\text { pemilihan konten-konten untuk } \\
\text { portal online }\end{array}$ & 1 \\
\hline & Seivieds & $\begin{array}{l}\text { Penyesuaian cara penyajian di portal } \\
\text { online }\end{array}$ & 2 \\
\hline & & $\begin{array}{c}\text { Memantau jumlah hit di website dan } \\
\text { melakukan pertimbangkan pada } \\
\text { pendapat pembaca }\end{array}$ & 4 \\
\hline$\stackrel{\stackrel{0}{\Xi}}{>}$ & Procurement & $\begin{array}{c}\text { Kepemilikan gedung kantor pusat } \\
\text { aktivitas redaksi }\end{array}$ & 1 \\
\hline$\underset{\substack{0 \\
=}}{\substack{0 \\
=}}$ & & $\begin{array}{l}\text { Kepemilikan personal computer yang } \\
\text { memadai }\end{array}$ & 4 \\
\hline Ë & Technology Developement & Jaringan internet/wifi & 4 \\
\hline$\stackrel{\rightleftarrows}{\rightrightarrows}$ & & Kepemilikan peranti lunak pendukung & 3 \\
\hline & & Perekrutan kru baru & 2 \\
\hline & $\begin{array}{l}\text { Human Resource } \\
\text { Management }\end{array}$ & $\begin{array}{l}\text { Pelatihan khususnya terkait } \\
\text { jurnalisme online dan media } \\
\text { dalam jaringan }\end{array}$ & 0 \\
\hline & & Pengembangan tenaga kerja & 0 \\
\hline & & Kompensasi untuk semua jenis personil & 0 \\
\hline & & Manajemen secara umum & 1 \\
\hline & & Perencanaan manajemen Mangle online & 1 \\
\hline & Firm Infrastructure & Urusan keuangan & 1 \\
\hline & & $\begin{array}{c}\text { Urusan peresmian laman website } \\
\text { Mangle secara hukum }\end{array}$ & 4 \\
\hline & & Pengecekan mutu manajemen & 1 \\
\hline
\end{tabular}

Berdasarkan analisis dengan menggunakan pendekatan value chain Michael Porter dan model maturity level, secara keseluruhan dapat dilihat bahwa meski banyak yang perlu dilakukan Mangle online dari nol karena belum pernah dilakukan sama sekali, namun ada juga aktivitas-aktivitas yang sudah berada pada jalur yang benar. Aktivitas-aktivitas yang telah dilakukan ini hendaknya tinggal diberikan pengembangan dan perbaikan agar pelaksanaannya sempurna dan semakin dekat ke arah tercapainya tujuan Mangle dalam beradaptasi di era digital. 
ISSN 2549-0559 (cetak) ISSN 2549-1946 (online)

Volume 02 Nomor 01 Tahun 2018

\section{Simpulan}

Berdasarkan penelitian yang dilakukan peneliti pada media Mangle mengenai adaptasi manajemen redaksinya di era digital, maka simpulan yang didapatkan oleh peneliti adalah sebagai berikut:

Pertama, pola kerja redaksi Mangle sebelum mengeluarkan portal online berlangsung cukup efektif mulai dari rapat redaksi penentuan konten hingga jadi sebuah majalah yang siap dijual. Setelah kemunculan Mangle online, terdapat perubahan dalam pola redaksi yang awalnya hanya meliputi penulisan berita yang dibuat ke versi berita online lalu bisa langsung diunggah oleh penanggung jawab portal online. Namun kemudian manajemen redaksi Mangle secara bertahap mengalami perubahan disebabkan karena kurangnya perencanaan yang matang dari awal pembuatan portal online.

Kedua, tujuan awal pembuatan portal online Mangle adalah untuk dapat menjangkau pembaca Mangle di luar Jawa dan terutama di luar Indonesia dan sebagai media promosi dari Mangle cetak. Ekspektasi yang diharapkan Mangle tentunya adalah para pembaca sasaran Mangle online tersebut dapat tetap menikmati konten yang disajikan dalam majalah Mangle, meski tidak berada di area-area Mangle didistribusikan. Namun, seiring berjalannya waktu, banyak keinginan lain yang ingin dicapai Mangle melalui portal onlinenya karena mereka menyadari fungsi media online yang lebih dari sekedar media promosi.

Terakhir, strategi yang dilakukan Mangle untuk beradaptasi di era digital dapat dikatakan belum mencapai standar yang seharusnya. Hal ini disebabkan karena proses perencanaan Mangle online yang tidak disiapkan dengan matang mulai dari pencarian informasi hingga pembentukan konsep yang sesuai dengan tujuan awal pembuatan Mangle online yang telah ditetapkan. Ketidakmatangan tahap perencanaan membuat ketiga fungsi manajemen lainnya tidak berjalan lancar. Berdasarkan value chain dari Michael Porter, aktivitas yang dilakukan Mangle dalam pembuatan dan pengelolaan Mangle online pun terbilang masih jauh dari baik. Terdapat 5 aktivitas yang belum dilakukan Mangle sama sekali dan 6 aktivitas dalam level undefined.

\section{Daftar Pustaka}

Albaran, A.B. (2005). Handbook of Media Management and Economics. New Jersey: Lawrence Erlbaum Associates.

Berger, A.A. (1995). Essentials of Mass Communication Theory. London: Sage Publication Inc

Lister, M. (2003). New Media: A Critical Introduction Second Edition. New York: Routledge

Morissan. (2008). Manajemen Media Penyiaran: Strategi Mengelola Radio \& Televisi. Jakarta: Prenada Media Group

Mulyana, D. (2007). Ilmu Komunikasi: Suatu Pengantar. Bandung: PT Remaja Rosda Karya

Porter, M. (1985). Competitive Advantage: Creating and Sustaining Superior Performance. New York: The Free Press.

Purwanto, I. (2012). Manajemen Strategi. Bandung: Penerbit Yrama Widya

Siapera, E. dan Andreas, V. (2012). The Handbook of Global Online 
24 | Kajian Jurnalisme

ISSN 2549-0559 (cetak) ISSN 2549-1946 (online)

Volume 02 Nomor 01 Tahun 2018

Journalism. UK: John Wiley \& Sons, Inc

Sukarna. (2011). Dasar-dasar Manajemen. Bandung: CV. Mandar Maju

Suprapto, T. (2006). Pengantar Teori Komunikasi. Yogyakarta : Media Pressindo.

Raco, J.R. (2010). Metode Penelitian Kualitatif; Jenis, Karakteristik dan Keunggulannya. Jakarta: PT Gramedia Widiasarana Indonesia.

West, R., dan Lynn H. T. (2008). Pengantar Teori Komunikasi: Analisis dan Aplikasi. Jakarta: Salemba Humanika

Wineu, W. (2012). Perkembangan Majalah Mangle di Bandung (1998-2012), (skripsi), Bandung, Universitas Islam Negeri Sunan Gunung Djati 